\title{
GUGATAN CLASS ACTION \\ DALAM HUKUM PERLINDUNGAN KONSUMEN
}

\author{
Wiwik Sri Widiarty ${ }^{1}$
}

\begin{abstract}
First time of the many cases that harm the interests of consumers as well as to the need for information and the development of knowledge in the field of law today is known as the class action, the Government, and Dewan Perwakilan Rakyat give attention to consumers in Indonesia. Provisions governing Class Action contained in Law No. 32 Year 2009 on Protection And Environmental Management, and Law No. 8 of 1999 on Consumer Protection, and also law PERMA No.1 Year 2002 on Proces Class Action. In order to demand justice for the consumer losses caused by the business, the consumer has the right to demand their rights as set out in the Consumer Protection Act, that the dispute mechanism can be chosen voluntarily by the parties to the dispute, namely through the courts or out of court. The class action suit is a civil lawsuit filed by a group of people who have an interest in a similar problem, either one or more of their members to sue or be sued as representative of the group without any members of the group are involved directly in the judicial process. In connection with this there is the benefit of a class action lawsuit in consumer disputes in court, but to fight for their rights, the principle litigants with simple, fast, and low cost, and the determinants that be a reason to be eligible class action, both in practice as well as in its implementation.
\end{abstract}

\section{Kata Kunci: Gugatan Class Action}

\section{Pendahuluan}

Gugatan Perwakilan Kelompok (class Action) dalam perkembangan hukum di Indonesia, sebagai langkah maju yang awalnya tumbuh dari masyarakat itu sendiri yang sadar akan hak-haknya sebagai warga negara. Kebutuhan informasi serta perkembangan pengetahuan tentang gugatan class action yang bersifat praktis saat ini sangat dirasakan. Dimana memberikan peluang bagi masyarakat untuk menuntut atau mempertahankan hak-haknya secara bersama-sama dengan cara perwakilan. Di Indonesia pemahaman konsep ini masih sangat baru, keengganan para konsumen yang dirugikan untuk mengajukan gugatan masih belum memahami akan hak-haknya yang dirugikan baik secara materiil maupun immaterial, dalam jumlah yang masih relative kecil, dan ini juga yang merupakan salah satu faktor para konsumen untuk menggugat haknya jika merasa dirugikan. Ketentuan yang mengatur gugatan kelompok (class action) ter-

${ }^{1}$ Dosen Tetap Fakultas Hukum UKI dapat dalam Pasal 91 Undang-Undang RI Nomor 32 Tahun 2009 Tentang Perlindungan Dan Pengelolaan Lingkungan Hidup, dan Pasal 46 Undang-undang Nomor 8 Tahun 1999 Tentang Perlindungan konsumen, gugatan perwakilan kelompok (class action) harus diajukan oleh konsumen yang benar-benar dirugikan dan dapat dibuktikan secara hukum, ser- ta Tata cara pengajuan class action yang diatur da- lam PERMA Nomor. 1 Tahun 2002 Tentang Acara Gugatan Perwakilan Kelompok. Hal ini merupakan salah satu syarat yang harus dipenuhi supaya dapat memberikan perlindungan kepada konsumen yang merasa dirugikan untuk mengajukan gugatan. Gugatan class action sudah digunakan di negara yang menganut system Common Law yaitu sistem yang menitikberatkan penciptaan kaidah hukum melalui putusan pengadilan. Indonesia sendiri penganut system Civil Law, Namun saat ini dalam praktinya Indonesia sudah menggunakan sejak tahun 1988 melalui gugatan yang diajukan oleh Wahana Lingkungan Hidup (WALHI) Di Pengadilan Negeri Jakarta. Gugatan Class action pertama kali diterapkan di Inggris 
pada abad ke 17, namun prosedur gugatannya baru dirumuskan dalam undang-undang di Amerika Serikat yaitu US Federal Rule Of Civil Procedure pada tahun 1938, dan diundangkan pada tahun $1966 .{ }^{2} \mathrm{Se}-$ belum tahun 1873 penerapan class Action di Inggris hanya diperkenalkan pada Court of Chancery. Baru kemudian pada tahun 1873, dengan diundangkannya Supreme Court Judicature Act di Inggris, Class Action kemudian dikembangkan di Amerika Serikat, Kanada, dan Australia berdasarkan konsep dan praktik yang berkembang di Inggris pada awal abad 17 tersebut. $^{3}$

Di Indonesia pengertian gugatan perwakilan (class Action) telah diberikan oleh beberapa peraturan diantaranya:

1. Undang-undang RI Nomor 32 Tahun 2009 Tentang Perlindungan Dan Pengelolaan Lingkungan Hidup, istilah yang digunakan untuk class Action adalah Gugatan perwakilan yang pada intinya adalah gugatan yang dapat diajukan oleh beberapa orang korban mewakili diri mereka sendiri, maupun korban-korban lainnya yang memiliki kesamaan masalah fakta, maupun tuntutan hukumnya.

2. Undang-Undang RI Nomor 8 Tahun 1999 Tentang Perlindungan Konsumen, istilah yang digunakan untuk Class Action adalah gugatan kelompok. Di dalam Penjelasan Pasal 46 Undang-undang ini disebutkan, bahwa gugatan yang diajukan oleh konsumen yang benar-benar dirugikan dan dapat dibuktikan secara hukum, salah satu diantaranya adalah bukti transaksi.

3. Undang-undang RI Nomor. 41 Tahun 1999 Tentang Kehutanan.

4. Peraturan Mahkamah Agung (PERMA) Nomor. 1 Tahun 2002 Tentang Acara Gugatan Perwakilan Kelompok.

Di Indonesia dalam perkembangan perlindungan hukum, masyarakat bisa melakukan upaya hukum melalui gugatan perwakilan (class action) dan Hak gugat organisasi (legal standing/Ius Standi), yang sama-sama mengalami atau menderita suatu kerugian.
Istilah Legal Standing dapat diartikan secara luas yaitu akses orang perorangan ataupun kelompok, organisasi di pengadilan sebagai pihak penggugat.

Legal Standing, Standing to sue, Ius Standi, Locus Standi, dapat diartikan sebagai Hakseseorang, sekelompok orang atau organisasi untuk tampil di pengadilan sebagai penggugat dalam proses gugatan perdata (Civil Proceding), atau sebagai "Hak Gugat". ${ }^{4}$ Rumusan Legal Standing telah diatur secara tegas dalam Pasal 38 Undang-undang Nomor 23 Tahun 1997 Tentang Pengelolaan Lingkungan Hidup, yang menyebutkan Organisasi lingkungan hidup berhak mengajukan gugatan untuk kepentingan pelestarian fungsi lingkungan hidup. Istilah organisasi lingkungan hidup ini sendiri kemudian menjadi kontroversial, karena menggantikan istilah Lembaga Swadaya Masyarakat (LSM) yang merupakan istilah telah mengakar dan menyatu dalam masyarakat.

\section{PERMASALAHAN}

Ada beberapa permasalahan dalam tulisan ini adalah sebagai berikut:

1. Apakah manfaat dan pertimbangan gugatan Class Action dalam sengketa konsumen di pengadilan Indonesia?

2. Apakah yang menjadi faktor-faktor penentu agar suatu gugatan konsumen dapat dikategorikan sebagai gugatan Class Action?

3. Bagaimana praktik atau pelaksanaan gugatan Class Action di Indonesia?

\section{TUJUAN PENULISAN}

Penulisan ini dilakukan dengan tujuan untuk mengetahui:

1. Manfaat dan pertimbangan gugatan Class Action dalam sengketa konsumen di pengadilan Indonesia;

2. Faktor-faktor penentu suatu gugatan konsumen dapat dikategorikan sebagai gugatan Class Action

3. Praktik atau pelaksanaan gugatan Class Action jika benar-benar mengakibatkan kerugian terhadap sekelompok konsumen.

\footnotetext{
${ }^{2}$ Mas Achmad Santosa, Civil Liability For Environmental Damage Indonesia, Disampaikan dalam pelatihan hukum lingkungan di Indonesia bekrjasama dengan Autralia, Jakarta: ICEL, 1999, hal.7

${ }^{3}$ MARI, Proyek Pembinaan Teknis Yustisial, Jakarta : PPTY, 1998, hal.75.
}

\footnotetext{
${ }^{4}$ Mas Achmad Santosa, op. cit. hal,3.
} 


\section{MANFAAT GUGATAN CLASS ACTION}

Gugatan perdata yang melibatkan jumlah orang yang menderita kerugian sangat banyak atau bersifat masif atau masal, maka Class Action sangat bermanfaat untuk dikembangkan di Indonesia. Berbagai manfaat tersebut dapat dijelaskan sebagai berikut: ${ }^{5}$

1. Class Action bermanfaat, karena proses berperkara menjadi sangat ekonomis (judicial economy). Dengan gugatan class action penggalangan (repetition) gugatan-gugatan serupa secara individual dapat dicegah. Tidaklah ekonomis bagi pengadilan apabila harus melayani gugatan-gugatan sejenis secara individual. Manfaat ekonomis tidak hanya saja dirasakan oleh penggugat akan tetapi oleh tergugat, sebab dengan class action tergugat hanya satu kali mengeluarkan biaya untuk melayani gugatan pihak-pihak yang dirugikan.

2. Class Action memberikan akses pada keadilan (access to justice). Apabila gugatan diajukan secara individual, maka akan mengakibatkan beban bagi calon penggugat, seringkali beban semacam itu menjadi hambatan bagi seseorang untuk memperjuangkan haknya di pengadilan. Terlebih lagi apabila biaya gugatan yang kelak akan dikeluarkan tidak sebanding dengan tuntutan yang akan diajukan. Melalui prosedur class action, kendala yang bersifat ekonomis ini dapat teratasi dengan cara orang-orang yang menderita kerugian menggabungkan diri bersama-sama class members lainnya dalam satu gugatan, yaitu gugatan class action.

3. Class action dimaksudkan untuk merubah si- kap pelaku pelanggaran (behavior modification). Dengan diterapkannya prosedur class action berarti memberikan akses yang lebih luas bagi pencari keadilan untuk mengajukan gugatan dengan biaya yang lebih efisien (cost efficiency). Akses class action dengan demikian berpeluang mendorong perubahan sikap dari mereka yang berpotensi merugikan kepentingan masyarakat luas. Peluang semacam ini disebut peluang untuk menumbuhkan efek penjera (deterrent effect).

\footnotetext{
${ }^{5}$ Hotma Timbul Hutapea, Class Action Konsumen Elpiji, Upaya memperjuangkan Hak dan Ganti Rugi, Makalah disampaikan dalam forum dialog konsumen elpiji di Hotel Wisata Internasional, Jakarta 1, 2001, hal.5.
}

Menurut Ridwan Syahrani, manfaat digunakannya gugatan perwakilan kelompok atau class action adalah: ${ }^{6}$

1. Penghematan waktu, biaya dan tenaga justru, karena gugatan tidak diajukan setiap anggota masyarakat atau kelompok, tetapi diakumulasikan dalam satu gugatan.

2. Adanya nilai pemberdayaan warga masyarakat untuk menggapai keadilan, karena tidak memperjuangkan sendirian melainkan bersama-sama dengan anggota masyarakat yang lain.

3. Pelaku pelanggaran hukum akan mengubah perilakunya dengan tidak mudahnya mengabaikan kepentingan pihak lain di masa depan.

Menurut Made Darma ada beberapa manfaat adanya gugatan class action yaitu: ${ }^{7}$

1. Bagi para pencari keadilan akan lebih mudah untuk mengajukan gugatan dengan model ini, sehingga tidak ada kekhawatiran ditolaknya suatu gugatan hanya karena masalah procedural semata.

2. Diterimanya gugatan ini para produsen akan berpikir seribu kali untuk melalaikan kewajibannya akan menimbulkan suatu akibat hukum tertentu, yang terpenting adalah perlindungan dan pengakuan terhadap hak-hak konsumen.

3. Diterimanya model gugatan ini akan menciptakan peradilan yang cepat, sederhana dan biaya yang ringan karena gugatan tidak perlu diajukan satu persatu dan hakimpun tidak kewalahan dalam mengadili suatu perkara yang sama.

Sebenarnya ada manfaat yang lain yang dapat dicapai dengan menggunakan prosedur mekanisme class action yaitu mencegah terjadinya inkosisten- si keputusan dan penafsiran hukum apabila hakim menyidangkan suatu perkara dan tuntutan yang sejenis, karena dimungkinkan bagi seorang hakim untuk mendapatkan nilai sendiri akan suatu kasus yang dihadapi. Sesuai semangat dan amanat dari undang-undang mengenai Ketentuan Pokok Kekuasaan Kehakiman yang menyatakan, hakim harus merdeka dalam membuat suatu keputusan di pengadilan, sehingga dikuatirkan apabila kasus yang sama dan sejenis disidangkan oleh hakim yang berbeda serta menghasil-

\footnotetext{
${ }^{6}$ Ibid.

${ }^{7}$ Galenter, Marc, Why Haves, Comes Out a Head, a presentation on Robert Steven's Seminar, Yale School: New Haven, 1997, hal. 127.
} 
kan keputusan yang beragam maka akan dapat menjadi suatu preseden yang kurang baik terhadap kasus yang sama di masa mendatang".

Di dalam bidang hukum yang menyangkut kepentingan publik, lembaga class action mempunyai kedudukan yang strategis. ${ }^{8}$ Strategis dalam arti memberikan akses yang lebih besar bagi masyarakat, terutama yang kurang mampu baik secara ekonomis maupun struktural, untuk menuntut apa yang menjadi hak-hak mereka yang bersifat publik, misalkan hak kesehatan, hak pendidikan yang layak, hak atas lingkungan hidup yang bersih dan sehat.

Ontario Law Reform Commission melihat ada tiga (3) manfaat utama yang dapat diketahui dari prosedur class action, yakni: ${ }^{9}$

1. Mencapai keadilan ekonomis

2. Memberi peluang yang lebih besar ke pengadilan

3. Merubah perilaku yang tidak pantas dari para pelanggar atau orang-orang yang potensial melakukan pelanggaran.

Pengajuan gugatan class action merupakan suatu cara untuk memudahkan pencari keadilan untuk mendapatkan pemulihan hak hukum yang dilanggar melalui jalur keperdataan. Bahwa sangatlah tidak praktis apabila kasus yang menimbulkan kerugian terhadap banyak orang, memiliki fakta-fakta atau dasar hukum, serta tergugat yang sama, diajukan secara sendiri-sendiri, sehingga menimbulkan ketidak efisiensi bagi para pihak yang mengalami kerugian, maupun pihak tergugat bahkan kepada pihak pengadilan sendiri.

\section{FAKTOR GUGATAN CLASS ACTION}

Pihak-pihak yang dirugikan dapat menuntut haknya, baik secara individual maupun secara kumulasi ataupun Class Action. Namun konsumen masih belum memahami akan hak-haknya jika dirugikan, para konsumen enggan untuk menggugat secara perwakilan kelompok, ini salah satu faktor konsumen untuk memperjuangkan hak-haknya melalui gugatan class action. ${ }^{10}$ Class Action merupakan salah satu spesia-

\footnotetext{
${ }^{8}$ Ontario Law Reform Commision, Report on Class Action, vol.1, Kanada : Ontario, 1982, hal.251

${ }^{9}$ Mary Kay Kane, Civil Procedur, The Three Edition, Minnesota : West Publishing Co St, 1991, hal.251.

${ }^{10}$ AZ Nasution, Hukum Perlindungan Konsumen Suatu Pengantar, Jakarta : Diadit Media, 2001, hal. 239.
}

lisasi prosedur pengajuan gugatan yang melibatkan orang banyak sebagai pihak dengan atau lebih tuntutan. ${ }^{11}$ Apabila para pihak ingin mengajukan gugatan secara class action terlebih dahulu harus dipenuhi beberapa syarat antara lain:

1. Sejumlah besar orang

Ketentuan tentang Class Action di berbagai negara pada umumnya mensyaratkan, bahwa jumlah orang yang mengajukan gugatan harus sedemikian banyaknya (numerous persons), sehingga apabila gugatan diajukan secara individual atau secara kumulasi akan menjadi tidak praktis lagi. Syarat ini dikenal di Inggris, Amerika Serikat, Quebec, New South Wales, South Australia dan India. Di negara-negara tersebut tidak ada ketentuan yang menyebutkan batas minimum serta batas maksimum jumlah anggota kelompok, agar gugatan boleh diajukan dengan prosedur Class Action.

2. Kepentingan yang sama

Di Amerika Serikat, syarat adanya kesamaan kepentingan dirumuskan sebagai, adanya kesamaan permasalahan hukum dan fakta (common question of law and fact). Hal ini dapat dilihat di dalam ketentuan R. 23. ${ }^{12}$

Di dalam sistem Federal Australia, syarat kesamaan kepentingan dirumuskan sebagai, dasar dari tuntutan terhadap orang yang sama, yang muncul dari situasi-situasi (circumstances) yang sama, serupa, atau berhubungan satu dengan yang lain. Dari berbagai rumusan ketentuan tentang syarat tersebut, maka dalam pengajuan gugatan secara Class action harus ada kesamaan kepentingan, yakni adanya kesamaan permasalahan tentang fakta dan hukum antara pihak yang mewakili dengan pihak yang diwakili sebagaimana dikemukakan oleh Kene, bahwa syarat adanya kesamaan kepentingan tidak hanya ditujukan pada prosedur Class action saja akan tetapi juga terhadap gugatan yang melibatkan pihak lebih dari satu yang diajukan secara kumulasi. ${ }^{13}$

Tuntutan Class Action dapat meliputi tuntutan ganti kerugian, tuntutan pernyataan bahwa suatu kelompok berhak atas ganti kerugian serta tuntu-

\footnotetext{
${ }^{11}$ Mas Ahmad Santoso, op.cit., hal.3-4

${ }^{12}$ Ibid.

${ }^{13} \mathrm{Ibid}$.
} 
tan perintah bagi tergugat untuk melakukan perbuatan tertentu.

\section{Wakil Kelompok}

Wakil kelompok yang jujur dan benar-benar mewakili kepentingan kelompoknya. Apa yang dituntut oleh wakil kelompok harus benar-benar merupakan kepentingan kelompok, bukan kepentingan wakil kelompok secara pribadi saja. Dalam pengajuan gugatan secara class action, salah satu permasalahan penting adalah tentang menentukan wakil kelompok yang dipandang jujur dan mampu menyuarakan kepentingan kelompok yang diwakilinya.

Untuk menentukan wakil kelompok yang benarbenar mampu menyuarakan kepentingan kelompok yang diwakilinya merupakan wewenang hakim sepenuhnya dan wakil kelompok harus dapat meyakinkannya kepada hakim. ${ }^{14}$ Karena kemampuan wakil kelompok merupakan masalah penting. Menurut Kane, Hakim harus memeriksanya sampai pada pokok perkara gugatan yang diajukan secara Class Action dan tidak hanya pada hak awal diajukannya gugatan saja. ${ }^{15}$

Santoso mengungkapkan pengalaman-pengalaman praktis dalam melaksanakan class action di Australia sehubungan dengan upaya untuk menetapkan kriteria wakil kelompok yang dianggap jujur dan benar-benar mampu mewakili kepentingan kelompoknya. Pengalaman-pengalaman tersebut antara lain: ${ }^{16}$

a. Wakil kelompok haruslah orang-orang atau orang yang mempunyai bukti yang paling kuat dan mampu meyakinkan hakim.

b. Wakil kelompok haruslah orang-orang atau orang yang terpercaya (trustworthy), dan terhormat.

c. Wakil kelas haruslah orang-orang atau orang yang tidak mendahulukan pribadi.

d. Jumlah serta komposisi wakil kelas juga harus mempertimbangkan aspek representativeness dari kelompok.

e. Akan lebih baik apabila wakil kelompok memiliki legitimasi sebagai pemimpin atau kepala adat.

\footnotetext{
${ }^{14}$ Mary Kay Kane, Op Cit, hal.67.

${ }^{15} \mathrm{Ibid}$.

${ }^{16}$ Shidharta, Hukum Perlindungan Konsumen Indonesia, edisi revisi, Jakarta : Grasindo, 2006, hal.67.
}

f. Pengacara harus juga membangun hubungan yang baik dengan wakil kelompok.

g. Wakil kelompok haruslah orang yang berani mengambil risiko.

4. Kewajiban memberitahukan kepada seluruh anggota kelompok

Ada 2 (dua) pandangan terhadap hal ini yaitu:

a. Wakil kelompok harus memberitahukan adanya gugatan class action kepada seluruh anggota kelompok yang diwakilinya.

b. Wakil kelompok tidak harus memberitahukan adanya gugatan class action kepada seluruh anggauta kelompok yang diwakilinya.

Peraturan yang mengatur gugatan class action di Indonesia yaitu, Peraturan Mahkamah Agung mengatur tata cara pengajuan gugatan perwakilan kelompok, dimana aturan ini tidak menyebutkan substansi atau jenis perkara yang dapat diajukan melalui mekanisme gugatan perwakilan kelompok.

Di Amerika Serikat dan Kanada Class action dapat diterapkan untuk segala jenis gugatan sepanjang memenuhi persyaratan dan mekanisme gugatan. Kasus- kasus tersebut juga bervariasi antara lain:

1. Perbuatan melawan hukum misalnya, meliputi kasus tanggung jawab produk, alat pemicu jantung yang mal fungsi, transplantasi payudara, hepatitis c, dan penularan HIV melalui system bank darah.

2. Perbuatan melawan hukum secara massal misalnya, kecelakaan kereta api, polusi air, pelecehan seksual di sekolah.

3. Kasus-kasus kontrak meliputi class action konsumen misalnya, melawan perusahaan-perusahaan kartu kredit yang menetapkan bunga bank secara illegal, penyesatan dalam pembangunan perumahan, tidak dibayarkan manfaat asuransinya, dan lain-lain.

4. Aksi pemecatan massal yang salah setelah pengambilalihan perusahaan.

5. Berbagai kasus lain seperti, sengketaperusahaan, kompetisi harga barang, waralaba, dana pensiun, bencana alam, hak atas tanah adat, dan hak cipta

6. Karyawan suatu perusahaan yang menderita kerugian karena praktik-praktik diskriminasi yang tidak adil (discrimination) seperti perbedaan ras, umur, gender. 
7. Perkara-perkara yang berkaitan dengan pencemaran lingkungan dan pelanggaran hak asasi manusia.

8. Pasien yang mengkomsumsi obat-obatan yang tidak diberi penjelasan yang cukup yang memberikan efek samping yang berbahaya bagi penggunanya.

9. Kerugian-kerugian yang disebabkan oleh bisnis curang atau pelanggaran terhadap Undang-undang Anti monopoli (financial losses resulting from violation antitrust law-anti competition Law).

10. Pedagang dan pembeli yang membeli produk kemahalan karena praktik-praktik persaingan yang curang yang dilakukan perusahaan (antitrust).

11. Investor yang menjadi korban karena perbuatan curang dalam kaitannya dengan pembelian saham dan securities lainnya (securities fraud).

Gugatan Class Action di Amerika semua perkara diajukan dengan ketentuan persyaratan persyaratan yang harus dipenuhi oleh si penggugat dan mewakili banyak korban yang bergabung menjadi kelompok, karena jika diajukan secara sendiri-sendiri menjadi tidak efektif. Kelompok yang mengajukan gugatan class action harus yang mempunyai kesamaan substansi hukum, dan fakta hukum.

Pasal 23 Federal Rule menetapkan persyaratan class action, yaitu: ${ }^{17}$

- Numerosity: Jumlah penggugat (class) harus sedemikian banyak sehingga melalui gugatan biasa (joinder), menjadi tidak praktis;

- Commonality: Harus terdapat kesamaan "question of law atau question of fact" diantara wakil dan anggota class.

- Typicality: Tuntutan maupun pembelaan dari wakil kelas haruslah sejenis (typical) dengan anggauta kelas;

- Class Protection/Adequacy of Reprensentation; wakil kelas harus secara jujur dan sungguh-sungguh melindungi kepentingan dari anggota kelas.

Pasal 23 Federal Rule secara umum mengatur dan memberikan dasar hukum terhadap 3 (tiga) hal antara lain:

\footnotetext{
${ }^{17}$ Garry D Watson, Class Action Experience, New York : University Toronto, 1999, Hal. 8.
}

1. Class action dapat merupakan Class action sebagai penggugat (plaintiff class action), maupun class action sebagai tergugat (defendant class action);

2. Class action memberi otorisasi mengajukan permohonan yang tidak terkait dengan ganti kerugian uang (injunctive atau declaratory relief);

3. Class action yang memberi dasar tuntutan ganti kerugian uang (damage class action).

Dalam Pasal 23 Federal Rule Of Civil Procedure ini juga mengatur tentang mekanisme penentuan apakah sebuah gugatan dapat dikategorikan class action ataukah gugatan biasa melalui mekanisme "Judicial Certification” atau Preliminary certification test”.

Pada tahap awal gugatan class action, hakim pengadilan di Amerika Serikat melakukan penilaian, diistilahkan realistic appraisal tentang isu hukum dan faktual yang dipersoalkan, kemampuan pengacara, dan motivasi dari para pihak beserta pengacara. Penilaian (preliminary certification test) ini bersifat fleksibel dan sangat tergantung diskresi hakim.

Tujuan Preliminary certification test disini adalah:

1. Apakah gugatan memenuhi kriteria atau kondisi dasar untuk pengajuan class action;

2. Apakah class action merupakan upaya benar-benar efisien dan berpegang pada prinsip keadilan (fair);

3. Apakah wakil kelas (representative parties) secara jujur dan sungguh dapat melindungi kepentingan anggota kelas. ${ }^{18}$

Untuk class action yang melibatkan soal ganti kerugian class action, persyaratan tambahan diberlakukan. Yaitu, Kewajiban menyampaikan pemberitahuan (individual notice) kepada seluruh anggautakelas dengan cara-cara yang reasonable. Pemberitahuan ini memberi kesempatan apabila terdapat anggota kelas melakukan "opt out".

Dalam kasus Wetzel versus Liberty Mutual Insurance Company yang terjadi di Amerika Serikat. Masuk dalam kategori Pasal 23 (b) Federal Rule.

Class action prosedur yang diharapkan dapat menjangkau sebanyak mungkin orang yang dapat

\footnotetext{
${ }^{18}$ Sundari, Pengajuan Gugatan Secara ClassAction (Suatau Studi Perbandingan Dan Penerapannya Di Indonesia), Yogyakarta : Universitas Atmajaya,1998, hal.76.
} 
menikmati hasil putusan, apalagi putusan yang memenangkan gugatan, sehingga tidak perlu lagi ada pengajuan gugatan lain. ${ }^{19}$

Di Australia class action pertama kali diperkenalkan oleh law reform commission of Australia. Di New South Wales terbentuk NGO yang memberi perhatian pada perkembangan class action, di Australia yakni coalition for class action, di bawah public interest Advocacy Centre (PIAC).

Pertama kali benua Australia mengakui class action untuk negara bagian New South Wales dan diatur di dalam New South Wales Supreme Court Rules (NSWSCR), 1970, Peradilan federal Australia kemudian juga memperkenalkan class action dan diatur di dalam Federal Court of Australian Act (FCAA), 1976. Berturut-turut class action berkembang di Negara-negara bagian lainnya. Seluruh Yurisdiksi Australia mengenai prosedur class action dan pada umumnya diatur sebagai salah satu ketentuan prosedur berperkara di dalam undang-undang yang mengatur hukum acara perdata. Dengan kata lain tidak diatur secara khusus tentang classs action dalam sebuah undang-undang. ${ }^{20}$

Pasal 23 Federal Rule secara umum juga mengatur tentang ganti kerugian yang memberikan dasar hukum terhadap 3 (tiga) hal antara lain:

1. Class Action dapat merupakan Class action sebagai penggugat (plaintiff class action), maupun class action sebagai tergugat (defendant Class actions);

2. Class action memberi otorisasi mengajukan permohonan yang tidak terkait dengan ganti kerugian uang (injunctive atau declaratory relief);

3. Class Action yang memberi dasar tuntutan ganti kerugian uang (demage class action).

Gugatan Class action yang melibatkan soal ganti kerugian (damage class action) persyaratan tambahan diberlakukan yaitu kewajiban menyampaikan pemberitahuan (individual notice) kepada seluruh anggota kelas dengan cara-cara yang reasonable. Pemberitahuan ini memberi kesempatan apabila terdapat anggauta kelas melakukan "opt Out" dan "Opt In". Opt in adalah prosedur yang dilakukan

\footnotetext{
${ }^{19}$ Ibid.

${ }^{20}$ Yudha Arif Budiman, Yayasan Lembaga konsumen Indonesia, Jakarta: YLKI, 2015, hal.1.
}

anggota kelompok dengan memberikan penegasan bahwa benar-benar anggota kelompok, sedangkan Opt Out adalah kesempatan anggauta kelompok untuk menyatakan dirinya ke luar dari class action dan tidak menghendaki jadi bagian dari gugatan.

\section{PRAKTIK GUGATAN CLASS ACTION}

Dalam perkembangannya konsep gugatan class action ternyata juga diterima dan dipraktikkan di negara-negara yang menganut sistem hukum Civil Law seperti di Indonesia sendiri mempunyai sebuah Lembaga konsumen yang diberi nama Yayasan Lembaga Konsumen Indonesia (YLKI), merupakan sebuah organisasi masyarakat yang bersifat nirlaba dan independen yang didirikan pada tanggal 11 Mei $1973 .{ }^{21}$ Tujuan didirikan Lembaga ini adalah untuk meningkatkan kesadaran kritis konsumen tentang hak dan tanggung jawabnya sendiri dan lingkungannya. ${ }^{22}$ Berbagai lembaga swadaya masyarakat seperti, YLKI, ICEL, APHI, dan LBH Jakarta, memberikan kuasa kepada dua puluh satu (21) pengacara, dengan melakukan upaya hukum class action yang dilakukan oleh Tim KAPAK LPG (Komite Advokasi Pemakai Anti Kenaikan LPG), sebagai pihak penggugat mewaki- li 200.000 jiwa konsumen LPG sejabotabek yang diwakili oleh 9 (sembilan) orang sebagai perwakilan kelompok (class action). ${ }^{23}$ Mewakili beberapa wilayah yang diwakilinya yaitu, wilayah Jakarta Pusat, jakarta selatan, jakarta timur, Jakarta Utara, Jakarta Barat, wilayah Bogor, wilayah Bekasi, wilayah Tangerang, serta konsumen anggota kelompok dari wilayah Depok. Kemudian sebagai tergugat 1, adalah Pertamina, dan Tergugat II Dewan Komisaris Pemerintah untuk Pertamina. Gugatan perkara didaftarkan di Pengadilan Negeri Jakarta Pusat dengan No.

\footnotetext{
${ }^{21}$ Ibid.

${ }^{22}$ Emerson Yuntho, Class Action Sebuah Pengantar, Bahan Materi Kursus HAM Untuk Pengacara, Jakarta : ELSAM, Lembaga Studi Dan Advokasi Masyarakat, 2005, hal.16.

${ }^{23}$ Undang-undang RI Nomor 8 Tahun 1999 Tentang Perlindungan Konsumen, Pasal 46, ayat (1), huruf b, mengatur gugatan atas pelanggaran Pelaku Usaha yang menyebutkan, 1). Seorang Konsumen yang dirugikan atau ahli waris yang bersangkutan. 2). Kelompok konsumen yang mempunyai kepentingan yang sama. 3). Lembaga Perlindungan Konsumen swadaya masyarakat, yaitu berbentuk badan hukum atau Yayasan, yang dalam anggaran dasarnya menyebutkan dengan tegas bahwa, tujuan didirikannya organisasi tersebut adalah untuk kepentingan perlindungan konsumen dan telah melaksanakan kegiatan sesuai dengan anggaran dasarnya. 4). Pemerintah dan/ atau instansi terkait apabila barang dan/atau jasa yang dikonsumsi atau dimanfaatkan mengakibatkan kerugian materi yang besar dan/atau korban yang tidak sedikit.
} 
550/ Pdt.G/2001. Bahwa dari para Penggugat yang merupakan Konsumen Gas elpiji, bermula dari SK Pertamina tentang kenaikan harga elpiji yakni, SK. No. Kpts-097/C00000/2000-S3, dimana kenaikan harga elpiji sekitar 40 persen dari harga sebelumnya. Kenaikan harga elpiji ini menimbulkan reaksi konsumen gas elpiji, karena proses kenaikan dilakukan secara sepihak tanpa adanya sosialisasi, yang dinilai bertentangan dengan hak-hak konsumen untuk mendapatkan informasi yang benar, jelas dan jujur, serta hak konsumen untuk mendapatkan kompensasi dan ganti kerugian sebagaimana diatur dalam UndangUndang RI Nomor. 8 Tahun 1999 Tentang Perlindungan Konsumen. ${ }^{24}$

Penggugat selain bertindak untuk dirinya sendiri juga sekaligus mewakili masyarakat konsumen gas elpiji pada tanggal 3 November Tahun 2000. Menggunakan mekanisme gugatan perwakilan kelompok (class action), yang diatur dalam Undang-Undang RI Nomor. 8 Tahun 1999 Tentang Perlindungan Konsumen, dan Undang-Undang RI Nomor 14 Tahun 1970 Tentang Pokok-Pokok Kekuasaan Kehakiman. Dimuat dalam salah satu pasalnya yang menyatakan, "Peradilan dilakukan dengan sederhana, cepat, dan biaya ringan" sebagai sifat perbuatan melawan hukum. Lalu kemudian pada proses peradilan tingkat pertama di Pengadilan Negeri Jakarta Pusat, hakim yang memeriksa perkara gugatan konsumen LPG dalam putusannya mengabulkan tuntutan Konsumen yaitu: $:^{25}$

1. Menyatakan perbuatan Pertamina menaikkan harga sebagai perbuatan melawan hukum;

2. Surat Keputusan yang dibuat dinyatakan cacat hukum dan tidak sah;

3. Mengakui secara hukum prosedur gugatan class action dengan diterimanya Sembilan orang wakil kelompok untuk mewakili kepentingan konsumen;

4. Dikabulkan ganti kerugian terhadap wakil kelas dan 200.000 konsumen yang diwakilinya.

Putusan Pengadilan Negeri ini merupakan putusan yang menggembirakan bagi para Penggugat, karena untuk pertama kali gugatan masyarakat den-

\footnotetext{
${ }^{24}$ Ibid, hal.17.

${ }^{25}$ Ibid.
}

gan menggunakan mekanisme Class Action dimenangkan. Meskipun di tingkat banding pihak penggugat dikalahkan. Namun ditingkat pengadilan negeri, majelis hakim memiliki pertimbangan lain, bahwa gugatan yang diajukan oleh penggugat dianggap telah memenuhi syarat-syarat untuk menyelesaikan sengketa melalui prosedur class action. Oleh majelis hakim yang terdapat dalam putusan selanya hakim memerintahkan kepada kedua belah pihak untuk melanjutkan perkara tersebut.

Melalui mekanisme prosedur beracara class action di tingkat pengadilan negeri, dan pengadilan tinggi, harus memenuhi syarat PERMA Nomor. 1 Tahun 2002 Tentang Tata Cara Gugatan Perwakilan kelompok, maka hal ini juga penggunaan mekanisme class action telah memenuhi syarat-syarat Numerousity Commonality, Typically, dan Adequuacy of, Representation, yang ditetapkan dalam Pasal 23 US Federal Rule Of Civil Procedure.

\section{KESIMPULAN}

1. Undang-Undang RI Nomor. 8 Tahun 1999 Tentang Perlindungan Konsumen, mengatur gugatan atas pelanggaran pelaku usaha, bagi Seorang Konsumen yang dirugikan atau ahli waris yang bersangkutan; Kelompok konsumen yang mempunyai kepentingan yang sama; Lembaga perlindungan konsumen swadaya masyarakat yang memenuhi syarat, yaitu berbentuk badan hukum atau yayasan, yang dalam anggaran dasarnya menyebutkan dengan tegas; Pemerintah dan/atau instansi terkait apabila barang dan/atau jasa yang dikonsumsi atau dimanfaatkan mengakibatkan kerugian materi yang besar dan/ atau korban yang tidak sedikit, dan manfaat dari gugatan Class action adalah proses berperkara yang bersifat ekonomis, Akses pada keadilan, dan perubahan sikap perilaku pelanggaran.

2. Gugatan perwakilan kelompok (class action) harus diajukan oleh konsumen yang benar-benar dirugikan dan dapat dibuktikan secara hukum, dan dengan kepentingan yang sama, harus memikirkan kepentingan kelompoknya, tidak adanya faktor-faktor yang bisa menghambat pengajuan gugatan class action, Harus benar-benar adanya secara nyata mengalami kerugian (concrete injured parties), adanya prinsip yang menjadi landa- 
san yang merupakan faktor utama konsep class action adalah prinsip numerousity, merupakan faktor yang menandakan suatu gugatan dimaksud mewakili kepentingan suatu kelompok yang terdiri dari banyak orang, Prinsip kesamaan (commonality), Adanya kesamaan kepentingan (same interest), adanya kesamaan penderitaan (same grievance), dan kesamaan tujuan (same purpose).

3. Praktik dan pelaksanaannya gugatan perwakilan kelompok (class action), prosedur gugatan kelompok diatur dalam PERMA nomor. 1 Tahun 2002 Tentang Acara Gugatan Perwakilan Kelompok, yang isinya mengatur persyaratan formil dalam hal diajukannya suatu gugatan kelompok, sesuai dengan rumusannya, gugatan kelompok berisikan tuntutan melalui proses pengadilan, yang diajukan oleh satu atau beberapa orang yang bertindak sebagai wakil kelompok.

\section{SARAN}

1. Bagi anggota yang menolak dapat dengan tegas menyatakan keluar dari kelompok (opt out) dengan cara memberitahukan terlebih dahulu kepada kelompok, sehingga kelompok dapat mengetahui dengan cepat.

2. Dalam putusan Pengadilan dengan adanya ganti kerugian, yaitu berupa uang ganti rugi (monetary damages) hendaknya sebanding dengan biaya dan kerugian yang dikeluarkan dan dialami oleh anggota kelompok, dan menentukan siapa saja yang berhak mendapatkan uang ganti rugi.

3. Dalam menangani perkara khususnya pada perkara Gugatan Class Action hakim hendaknya melakukan penemuan hukum, Karena pada perkara gugatan Class Action ini masih terbilang baru, dan belum ada undang-undang atau peraturan yang khusus menangani Gugatan Class Action Di Indonesia, oleh karena itu perlu dibuatkan undang-undang atau peraturan tersendiri khusus menangani tentang gugatan Class Action ini.

\section{Daftar Pustaka}

\section{Buku:}

AZ Nasution, Hukum Perlindungan Konsumen Suatu Pengantar, Jakarta: Diadit Media, 2001.

Emerson Yuntho, Class Action,Sebuah Penganta, Bahan Materi Kursus HAM, Jakarta: ELSAM, Lembaga

Studi Dan Advokasi Masyarakat, 2005.

Galenter, Marc, Why Haves, Cames Out A Head, Apresentation On Robert Steven Is Seminar, Yale School: New Haven, 1989.

Hensler R Deborah, The Globalisation On Class Action, Stanford Law School: An Overview, 1997.

Kay kane Mari, Civil Procedure, Edition Three, West Publishing Co St, Minnesota: United State of America, 1991.

Mas Ahmad Santoso, Sulaiman Sembiring, Hak Gugat Organisasi Lingkungan (Enviromental Legal Standing), Cetakan Pertama, Jakarta: IEEI, 1997.

MARI, Proyek Pembinaan Teknis Yustisia, Jakarta: PPTY, 1998.

Ontario Law Reform Community, Report On Class Action, Volume, 1, Kanada: Ontario, 1982.

Sidharta, Hukum Perlindungan Konsumen Indonesia, Edisi Revisi, Jakarta: Grasindo, 2006.

Sundari, Pengajuan Gugatan Secara Class Action (Suatu Studi Perbandingan Dan Penerapannya Di Indonesia), Yogjakarta: Universitas Atmadjaya Yogjakarta, 1998. 
Watson Garry, Class Actions Canadian Experience, New York: Toronto University, 1999.

Yudha Arif Budiman, Penanganan Kasus Di Yayasan Lembaga Konsumen Indonesia, Jakarta: YLKI, 2015

\section{Makalah:}

Hotma Timbul Hutapea, Class Action Elpiji, Upaya Memperjuangkan Hak Dan Ganti Rugi, Jakarta, 2001.

\section{Undang-Undang:}

Undang-Undang Republik Indonesia Nomor 8 Tahun 1999 tentang Perlindungan Konsumen. UndangUndang Nomor 32 Tahun 9 tentangPerlindungan dan Pengelolaan Lingkungan Hidup. Peraturan Mahkamah Agung RI Nomor 1 tahun 2002 tentang Acara Gugatan Perwakilan Kelompok. 